Nunn D. Sliding hip screws and medial displacement osteotomy. $J \boldsymbol{R}$ Soc Med 1988; $81: 140-2$.

Radford PJ, Needofi M, Webb JK. The Gamma nail compared to the dynamic hip screw for pertrochanteric fractures of the femur. Orthop Proc 1992; II :[In press].

Rosenblum SF, Zuckerman JD, Kummer FJ, Tam BS. A biomechanical evaluation of the Gamma nail. J Bone Joint Surg [Br] 1992; 74$B$ :(in press).
Royal College of Physicians of London. Fractured neck of femur: prevention and management. London: RCP, 1989.

Simpson AHRW, Varty K, Dodd CAF. Sliding hip screws: modes of failure. Injury 1989; 20:227-31.

Wolfgang GL, Bryant MH, O'Neill JP. Treatment of intertrochanteric fracture of the femur using sliding screw plate fixation. Clin Orthop $1982 ; 163: 148-58$.

\title{
Ceramic hips
}

Sir John Charnley (1979) concluded from the results of the McKee-Farrar metal-on-metal total hip replacement that high friction was the cause of failure. In the early sixties, he had introduced the concept of lowfriction arthroplasty based on a small head articulating with an ultra-high-molecular-weight polyethylene cup (UHMWP), all components being cemented. He foresaw that the plastic would wear at about $0.1 \mathrm{~mm}$ per year, but he thought that the consequences would be minor. Ten years later, however, concerns about UHMWP wear began to be expressed. Rose et al (1979) reported very precisely the mechanical behaviour of this material in laboratory tests, and in 1990 Willert, Bertram and Buchorn described the foreign-body reaction in vivo to wear particles and cement debris. The relative importance of these materials was not clear at this time, mainly because it was difficult to differentiate between them and to compare their effects. As more information became available, the cystic formations and areas of bone osteolysis around cemented stems gave rise to the concept of 'cement disease'. Howeiver, when trials of the use of uncemented components were undertaken in France by Judet et al (1978), Lord et al (1988) and others, similar cystic formations were described around uncemented femoral stems and, to a lesser extent, around uncemented acetabular cups. Histological examination of these cases suggested that UHMWP particles could be responsible for the foreign-body reaction. Many experimental and clinical results have confirmed this hypothesis. Goldring et al (1983) described the osteolytic effect of the synoviumlike membrane which surrounds loose prostheses. In vitro, UHMWP particles are even more powerful than cement in provoking macrophage reactions which lead

L. Sedel, MD, Professor of Orthopaedic Surgery Service de Chirurgie Orthopédique, Hôpital Saint-Louis, 1 Avenue C. Vellefaux, 75475 Paris 10, France.

(C) 1992 British Editorial Society of Bone and Joint Surgery $0301-620 X / 92 / 3372 \$ 2.00$

J Bone Joint Surg [Br] 1992; 74-B:331-2. to the stimulation of inflammatory mediators. In clinical practice, the high failure rate in heavy, active, young, male subjects correlates with excessive socket wear. Biochemically, it has been shown by Kim et al (1990) that prostaglandin $E_{2}$ and collagenase concentrations are similar in the tissues surrounding failed prostheses whether they are cemented or uncemented. 'Cement disease' may be, in fact, 'UHMWP disease', with the plastic wear debris acting as the weak link in long-term joint replacement in young, active subjects.

The use of alumina ceramics in endoprostheses began in 1970 when Boutin (1972) implanted an aluminaon-alumina total hip into a patient. From its applications in dentistry, the material was already known to be highly biocompatible and strong. Of special interest were its sliding characteristics due to its hardness and wettability. It was possible to obtain a very smooth surface which resulted, with appropriate clearance between the components, in low friction characteristics and very little wear debris.

The first clinical trials achieved only fair results, the initial difficulties including poor quality control of the alumina with respect to purity, density, and grain size. There were also problems in the design of the head-stem fixation system and mistakes in surgical technique. Some failures were unjustly attributed to the ceramic, as in the case of the Mittelmeier prosthesis, reported by Mahoney and Dimon (1990), in which many of the stem and cup failures were related to other aspects of the design.

Now, with more than 20 years' experience of its use, it is possible to manufacture safe, high-quality, resistant alumina ceramic implants. Some limitations remain: the size of the femoral head must not be too small or it may break and the articular surfaces must be very accurately designed, with a clearance of 15 to $40 \mu \mathrm{m}$ between the two alumina components. The surgeon must not hammer the ceramic head and he must accurately position the acetabular cup. Hammering may result in stress risers; positioning of the cup too vertically may cause point contact between the two components which could lead to dramatically increased wear. If these pitfalls are avoided the alumina-on-alumina hip prosthesis will produce about 
4000 times less wear debris than an equivalent metal or polyethylene design.

There are, therefore, distinct theoretical advantages in the use of such implants in active young patients and we reported a $94.6 \%$ survival rate at ten years in patients of 50 years of age or less (Sedel et al 1990). The results in older patients, however, are not as good due to a high rate of loosening of the cemented alumina socket. This may be related to the rigidity of the socket and to the brittleness of porotic bone in the elderly. If so, what will happen to acetabular cups in younger patients when they grow old? We do not know, but we hope that the remodelled bone will continue to adapt in the long term as has happened around some uncemented acetabular cups (Boutin et al 1988).

A ceramic head articulating with a UHMWP socket is another possibility. In the laboratory this combination produces four times less wear debris than a metal-onplastic bearing but in clinical practice the long-term gain has proved less spectacular. The reasons for this are not understood. Perhaps there is more creep of the UHMWP against the hard ceramic material. Increased heat generation and the effects of cement debris entrapment may also play a part.

Are the days of the metal-on-UHMWP hip implant over? We think not. Improvements continue in the making of metal heads and in the quality of UHMWP. They are cheap and the overall clinical results at ten years with this combination of materials have yet to be bettered by other configurations. There is probably a place for a variety of designs, however, to match the different pathological and clinical indications, including the patients' age, activity level, bone quality and life expectancy. In young active people the best long-term results may be expected from an implant with the least rate of wear and at present alumina-on-alumina surfaces are the best.

LAURENT SEDEL

\section{REFERENCES}

Boutin P. Arthroplastie totale de la hanche par prothèse en alumine frittée: etude experiméntale et premières applications cliniques. Rev Chir Orthop 1972; 58:229-46.

Boutin P, Christel P, Dorlot J-M, et al. The use of dense aluminaalumina ceramic combination in total hip replacement. $J$ Biomed Mater Res 1988; 22:1203-32.

Chamley J. Low friction arthroplasty of the hip: theory and practice. Berlin, etc: Springer-Verlag, 1979.

Goldring SR, Schiller AL, Roelke M, et al. The synovial-like membrane at the bone-cement interface in loose total hip replacements and its proposed role in bone lysis. J Bone Joint Surg [Am] 1983; 65A:575-84.

Judet R, Siguier M, Brumpt R, Judet T. A noncemented total hip prosthesis. Clin Orthop 1978; 137:76-84.

Kim KJ, Wilson SC, D'Antonio JA, McClain EJ, Rubash HE. Comparison study of interface tissues in cementless and cemented prostheses. Orthop Trans 1990; 14:385.

Lord G, Marotte JH, Blanchard JP, et al. Cementless madreporic and polarised total hip prostheses: a ten-year review of 2688 cases. French J Orthop Surg 1988; $2.1: 82-92$.

Maboney OM, Dimon JH III. Unsatisfactory results with a ceramic total hip prosthesis. J Bone Joint Surg [Am] 1990; 72-A:663-71.

Rose RM, Crugnola A, Ries M, et al. On the origin of high in vivo wear rates in polyethylene components of total hip prostheses. Clin Orthop 1979; 145:277-86.

Sedel L, Kerboull L, Christel P, Meunier A, Witvoet J. Alumina-onalumina hip replacement: results and survivorship in young patients. J Bone Joint Surg [ Br] 1990; 72-B :658-63.

Willert HG, Bertram H, Buchorn GH. Osteolysis in alloarthroplasty of the hip: the role of ultra-high molecular weight polyethylene wear particles. Clin Orthop 1990; 258:95-107.

\section{Ionising radiation and the orthopaedic surgeon}

The use of ionising radiation has been an integral and essential part of the practice of orthopaedic surgery for almost a century. The introduction of new procedures such as closed, locked, intramedullary nail fixation of fractures of the long bones has resulted in the increased use of fluoroscopic screening in the orthopaedic theatre. Ionising radiation has therefore become a serious

D. E. Hynes, FRCS Ed, FRCS Ed(Orth), Orthopaedic Senior Registrar Beaumont Hospital, PO Box 1297, Beaumont Road, Dublin 9, Republic of Ireland.

T. Conere, MSc, PhD, CPhys, Principal Physicist

M. B. Mee, BSc, MIPSM, Chief Physicist

W. F. Cashman, FRCS, FRCS I, Consultant Orthopaedic Surgeon

Cork Regional Hospital, Wilton, Cork, Republic of Ireland.

Correspondence should be sent to Mr D. E. Hynes.

(C) 1992 British Editorial Society of Bone and Joint Surgery 0301-620X/92/3399 \$2.00

J Bone Joint Surg [Br] 1992; 74-B:332-4. occupational hazard for orthopaedic surgeons and other theatre staff who are often ill-informed on the subject and poorly trained to minimise the associated health risks.

Exposure to ionising radiation can be associated with a range of harmful effects such as sterility and damage to the lens of the eye. These so-called 'deterministic effects' can be avoided if the dose is kept below the tissue-specific threshold dose for that particular effect. On the other hand, 'stochastic effects', for which there may be no threshold dose, can result in the subsequent development of neoplasms after a latent period which may vary from years to decades, depending on the type of cancer. Unfortunately, there is considerable uncertainty about predicting the possible stochastic effects of long-term low-dose occupational exposure, mainly because statistically significant data on the effects in exposed human populations are available principally for 